\title{
A ACÇÃO DOS PIPKRAKES NA MORFOGÉNESE ACTUAL NA SERRA DO GERÊS
}

GONÇALO TELES VIEIRA ${ }^{1}$

\begin{abstract}
Resumo - Os pipkrakes são um processo morfogenético activo e com uma importante capacidade erosiva na Serra do Gerês, estando a sua formação relacionada com a ocorrência de períodos frios e secos anticiclónicos. São analisados os principais mecanismos através dos quais se processa a erosão por pipkrakes, bem como a micromorfologia por eles originada na Serra do Gerês. São formas que apresentam quase sempre um carácter efémero, sendo rapidamente destruídas pela erosão hídrica, que parece constituir o principal processo erosivo na área. Os pipkrakes surgem, assim, como um processo que desagrega o substrato, preparando-o para a erosão por outros processos.
\end{abstract}

Palavras-chave: pipkrake, Serra do Gerês, morfogénese actual, erosão, micromorfologia.

Abstract - Needle ICe Erosion in the Serra do Gerês (Nw Portugal) - After a short review of the studies on needle ice in the world, its morphogenetic significance in the Serra do Gerês is discussed. Several needle ice induced morphological features were identified in the field. Nevertheless, cryogenic features are in most cases ephemeral, being destroyed by the action of processes with higher morphogenetic capacity (i.e. runoff). Needle ice acts mostly as a disruptive agent, causing the desegregation of weathered granite or other non-cohesive deposits. The resultant material is easily transported by other processes, like runoff or wind. The more prone areas to needle ice formation are also discussed.

Key-words: needle ice, Serra do Gerês (NW Portugal), present-day morphogenesis, erosion.

\section{1 - INTRODUÇÃO}

O presente artigo é a síntese parcial de uma dissertação de mestrado dedicada ao estudo da morfogénese recente e actual na Serra do Gerês (VIEIRA, 1995).

O papel dos pipkrakes na erosão de solos e rególitos em Portugal é ainda pouco conhecido, embora a sua importância tenha sido referida (GIRÃO, 1940; REBELO, 1975; DAVEAU, 1978), ou mesmo analisada por alguns investigadores (PEDROSA, 1992, 1993; VIEIRA, 1995). A ideia de que o gelo tem um papel pouco importante na morfogénese actual, mesmo nas montanhas mais elevadas, exceptuando o sector cimeiro da Serra da Estrela, é geralmente aceite (DAVEAU, 1978; COUDÉ-GAUSSEN, 1981). O presente trabalho constitui uma contribuição para o estudo da influência dos pipkrakes na morfogénese das montanhas do Noroeste português, e mais concretamente, da Serra do Gerês.

A Serra do Gerês é um maciço granítico localizado no Noroeste de Portugal (fig. 1). A sua altitude máxima é de $1545 \mathrm{~m}$, atingidos na Nevosa, ponto que constitui a segunda maior elevação de Portugal Continental. Os interflúvios formam um planalto suavemente inclinado para sudoeste, que se encontra fortemente dissecado por vales em V. A influência da tectónica nas grandes formas é especialmente notória pela adaptação da rede hidrográfica à complexa rede de fracturas. É frequente encontrar, embutidos no planalto somital, retalhos planos escalonados, que parecem

\footnotetext{
1 Assistente da Universidade de Lisboa. Investigador do CEG. Centro de Estudos Geográficos, Faculdade de Letras de Lisboa, Cidade Universitária, 1699 Lisboa Codex. Tel.: (351-1) 7940218; Fax: (351-1) 7938690; E-mail: ulflgtvi@cc.fc.ul.pt ou ceg@mail.telepac.pt.
} 
corresponder a antigas superfícies de aplanamento (COUDÉ-GAUSSEN, 1981). Uma origem tectónica é também hipótese a considerar.
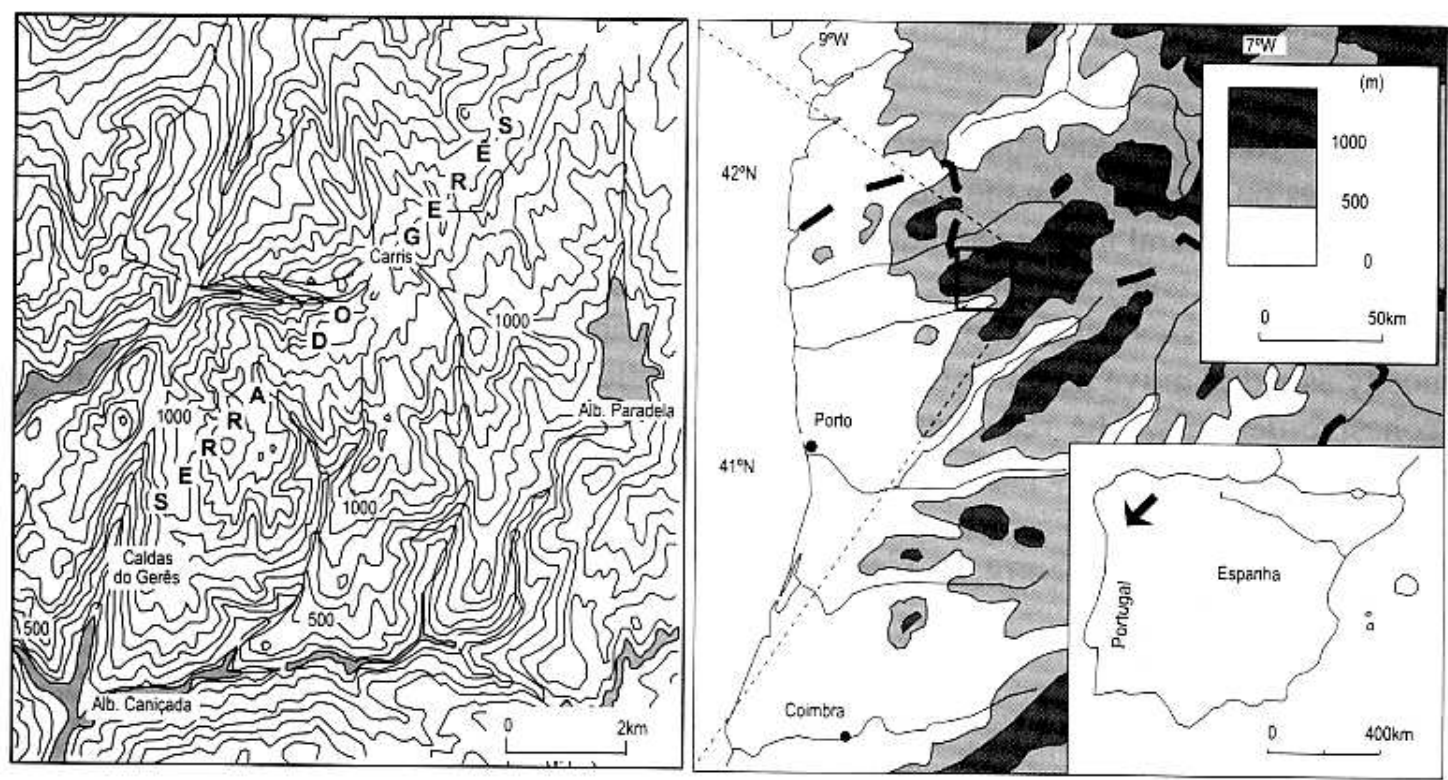

Figura 1 - Localização da Serra do Gerês

Figure 1 - Location of Serra do Gerês

Um aspecto muito significativo para a morfogénese é a diferença no coberto vegetal que se verifica entre os sectores superiores das vertentes e interflúvios, e os sectores inferiores das vertentes e fundos de vale. Nos primeiros dominam os afloramentos de rocha nua e a vegetação é esparsa e raquítica; nos segundos, o manto de alteração permite um maior desenvolvimento do coberto vegetal, sendo frequente a existência de floresta. Deste modo, a cobertura vegetal surge, na área estudada, como um reflexo da presença ou ausência do manto de alteração granítico. O limite entre o andar onde predomina o manto de alteração (étage des arènes - COUDÉ-GAUSSEN, 1981) e os sectores cimeiros onde dominam os afloramentos de rocha nua, embora variável, situa-se normalmente, a cerca de 800-900m de altitude.

A posição da Serra do Gerês no Noroeste de Portugal é determinante para as suas características climáticas. A área é influenciada pelas massas de ar húmido de trajectória oceânica, embora apresente ainda algumas características tipicamente mediterrâneas. É uma área extremamente húmida, sendo no entanto frequentes intervalos estivais secos e quentes. A precipitação média anual é elevada, atingindo mais de 3500mm nas áreas mais elevadas, enquanto o número médio anual de dias de precipitação varia entre 110 e 160 (DAVEAU et al., 1977). O regime da precipitação reflecte as características do clima mediterrâneo, ocorrendo os máximos nos meses de Inverno, Outono e Primavera, e os mínimos no Verão. A importância da erosão hídrica na morfogénese é facilmente perceptível pelos quantitativos máximos diários de precipitação. Um máximo de $337 \mathrm{~mm}$ foi medido no posto udométrico da Juncêda (1133 metros), correspondendo intensidades entre 126mm (Pedra Bela) e 200mm (Juncêda) em 24 horas, a um período de retorno de cinco anos para os diversos postos udométricos da Serra (dados recolhidos de "O Clima de Portugal", fasc. XIX, INMG, 1980).

Os registos térmicos para a área são muito escassos, apenas existindo dados para a estação climatológica do Gerês (situada a $480 \mathrm{~m}$ de altitude), que funcionou em 
apenas seis anos da década de cinquenta (1953-59). Os registos ilustram um regime térmico simples, ocorrendo a temperatura média mais elevada em Agosto $\left(21^{\circ} \mathrm{C}\right)$, e a mais baixa em Fevereiro $\left(8^{\circ} \mathrm{C}\right)$. A temperatura média anual nesse período foi de $14^{\circ} \mathrm{C}$. Com base no trabalho de DAVEAU et al. (1985), é possível estimar algumas características térmicas das áreas mais elevadas. Os autores apontam para mais de 40 dias com temperatura mínima inferior a $0^{\circ} \mathrm{C}$, e para uma temperatura mínima média do mês mais frio inferior a $1^{\circ} \mathrm{C}$. Para as temperaturas estivais, são sugeridos menos de 20 dias com um máximo superior a $25^{\circ} \mathrm{C}$ e uma temperatura máxima média do mês mais quente inferior a $23^{\circ} \mathrm{C}$. Infelizmente não existem quaisquer dados para o regime térmico do solo. As deficiências ao nível dos dados climáticos, especialmente no que se refere ao regime térmico do solo, tornam extremamente difícil o estudo da frequência de ocorrência de pipkrakes na área estudada. Este trabalho apresenta assim como principal objectivo a caracterização da influência deste processo na morfogénese actual, sendo deixadas de lado quaisquer inferências quanto à sua frequência de ocorrência.

\section{2 - O CONCEITO DE PIPKRAKE E OS PRINCIPAIS ESTUDOS EXISTENTES}

O termo pipkrake parece ter sido introduzido pela primeira vez na terminologia científica por HESSELMAN em 1907, tendo origem na língua sueca (LAWLER, 1989). "Deriva da conjugação de pipa, que significa tubo ou cano e de krake, que significa fraco e fino" (LAWLER, 1989, p. 408 citando HILlEFORS, 1976). Embora pipkrake seja usado frequentemente pelos investigadores latinos, e mesmo por alguns de língua alemã, o termo mais difundido entre os autores de língua inglesa é needle ice, que significa agulha de gelo. Em Portugal, o termo científico mais frequentemente usado é pipkrake, embora existam termos regionais para o fenómeno, os quais estão por nós actualmente a ser compilados.

Apesar de haver diversos tipos morfológicos de pipkrakes, as várias definições propostas não denotam incompatibilidades entre elas, mostrando antes pequenas adaptações resultantes do avanço recente que se tem verificado no seu conhecimento.

OUTCALT (1971, p. 394) usou a seguinte definição: "filamentos verticais de gelo com cerca de $1 \mathrm{~mm}^{2}$ de secção e com um comprimento até cerca de $10 \mathrm{~cm}$, formados pela segregação de gelo próximo da superfície do solo, durante noites de Inverno calmas e sem nuvens, tendo a parte superficial do solo estado descongelada, ou tendo derretido durante o dia..." (estampa I). 


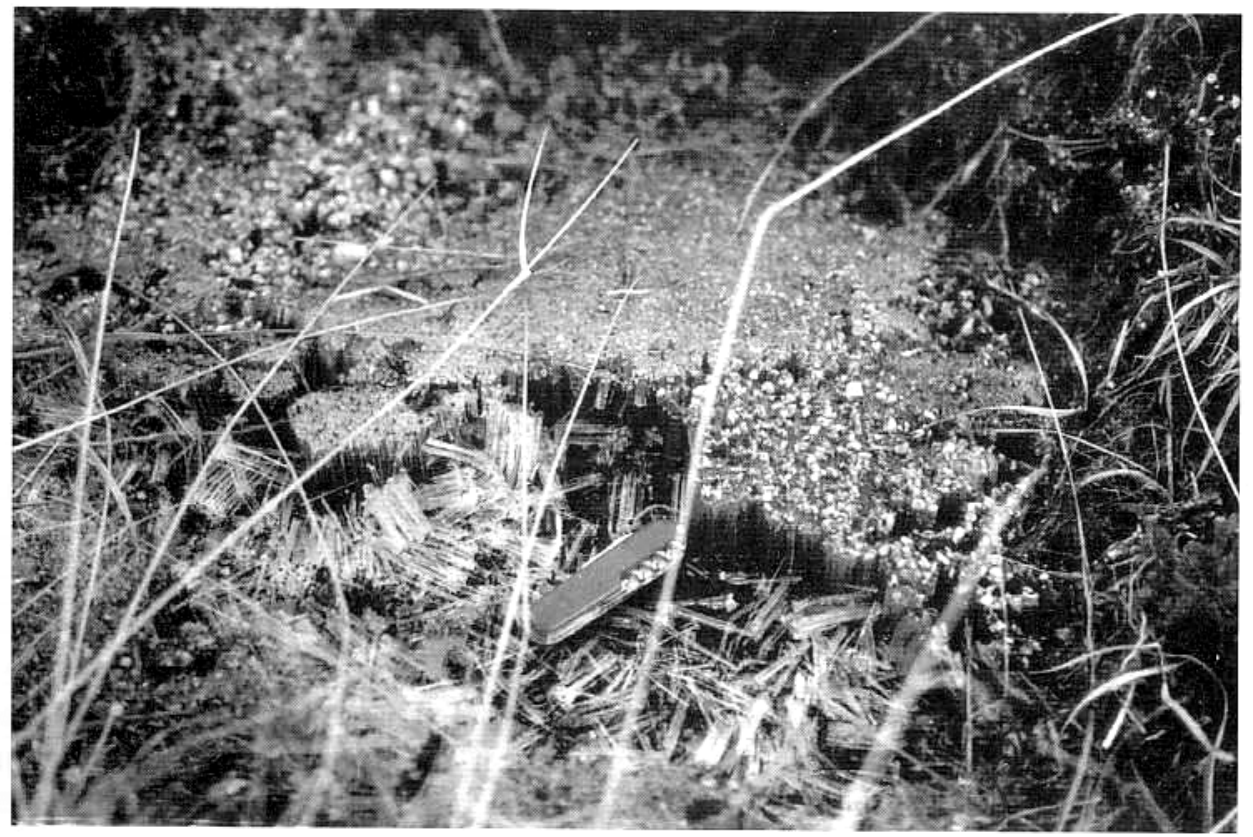

Estampa I - Pipkrakes sem e com cobertura de grânulos, rectilíneos e com cerca de $2 \mathrm{~cm}$ de comprimento (Outeiro do Pássaro, 1440m de altitude, 5/2/95)

Photo I - Rectilinear ice needles.

Por sua vez BRANSON et al. (1992, p. 357) definem pipkrake do seguinte modo: "é uma pequena forma de frost-heave ${ }^{2}$, produzida pela segregação de gelo desde uma frente de congelação estável na superfície do solo, ou logo abaixo dela. O seu crescimento está geralmente associado com ciclos gelo-degelo diurnos, afectando solos limosos ou matéria vegetal com suficiente alimentação de humidade".

A evolução verificada entre as duas noções apresentadas vem no sentido de numa definição simples se englobarem tipos de pipkrakes, que não se poderiam incluir no conceito de OUTCALT. Foi assim substituída uma definição de carácter fundamentalmente morfológico, por outra puramente genética. Na realidade, seria difícil incluir na primeira os pipkrakes de 35-40cm de comprimento descritos por KRUMME (1935, citado por WASHBURN, 1979), os de 50cm referidos por GEIGER (1980, p. 180), os que se desenvolviam a partir de um ramo de árvore, testemunhados por uma fotografia de PETKOVSEK, apresentada por WoODLEY (1988), ou aqueles que por nós foram observados, desenvolvidos sobre um clasto de granito (VIEIRA, 1995).

Segundo LAWLER (1989), parece ter sido ELLIOT (1824) o primeiro a referir a ocorrência de pipkrakes, tendo sido publicados outros trabalhos no séc. XIX, como por exemplo, os de HERSCHEl (1833), LE CONTE (1850), CASPARY (1854) e KoCH (1877). Segundo o mesmo autor, um artigo de ARGYLL (1880), terá dado início a um rico debate que, só naquele ano, levou à publicação de onze diferentes artigos na revista Nature. As observações de pipkrakes são desde então referidas ocasionalmente por diversos autores, tendo a sua compreensão sofrido importantes avanços através das experiências de laboratório. Foram naquele domínio especialmente importantes os trabalhos elaborados por OUTCALT na década de setenta (LAWLER, 1993, p. 84), que deram um grande contributo para o conhecimento dos factores condicionantes do crescimento dos pipkrakes. Mais recentemente, LAWLER (1986, 1987, 1989, 1993) tem estudado a importância dos pipkrakes no recuo das margens de cursos de água, aliando as suas observações de campo a estudos laboratoriais; PÉREZ (1986, 1987a,

2 Segundo WASHBURN (1979, p. 79), frost heave é o movimento, predominantemente para cima, que os solos minerais sofrem durante a congelação. 
1987b, 1987c, 1988, 1992a, 1992b) tem efectuado detalhadas observações de campo nos Andes venezuelanos, apoiadas por experiências de laboratório; BRANSON et al. (1992) desenvolveram uma minuciosa monitorização do crescimento de pipkrakes em laboratório, de forma a melhor compreenderem o processo de incorporação de material nos diferentes tipos de pipkrakes.

BRANSON et al. (1992, p. 357), baseados em OUTCALT (1971), salientam as três condições fundamentais para a formação de pipkrakes, que devem ser consideradas:

- ocorrer uma temperatura suficientemente baixa para sobrearrefecer a água à superfície do solo (aproximadamente $-2^{\circ} \mathrm{C}$ );

- existir suficiente humidade no solo para que se inicie a segregação de gelo;

- haver uma alimentação de água que traga calor latente suficiente para a frente de congelação, de forma a equilibrar as perdas caloríficas em direcção à superfície, assegurando uma frente de congelação estável.

\section{3 - MECANISMOS DE TRANSPORTE DE MATERIAL POR PIPKRAKES}

A divisão dos mecanismos de erosão por pipkrakes em mecanismos directos e indirectos, baseia-se na intervenção do pipkrake quanto à movimentação do material na vertente. Num mecanismo directo, o material movimenta-se na vertente directamente pela acção dos pipkrakes num único ciclo de gelo-degelo enquanto, num mecanismo indirecto, o movimento tem origem numa situação de aumento progressivo no desequilíbrio da superfície, pela acção cumulativa de vários episódios com formação de pipkrakes.

\section{1 - Mecanismos directos}

A importância dos pipkrakes como agente erosivo é um facto geralmente aceite (FRENCH, 1976). Estudos recentes (por exemplo LAWLER, 1993) e as observações de campo efectuadas na Serra do Gerês (VIEIRA, 1995), mostram que os mecanismos que causam o transporte do material por pipkrakes são diversos, podendo surgir tipos de movimento diferentes dos tradicionalmente apontados.

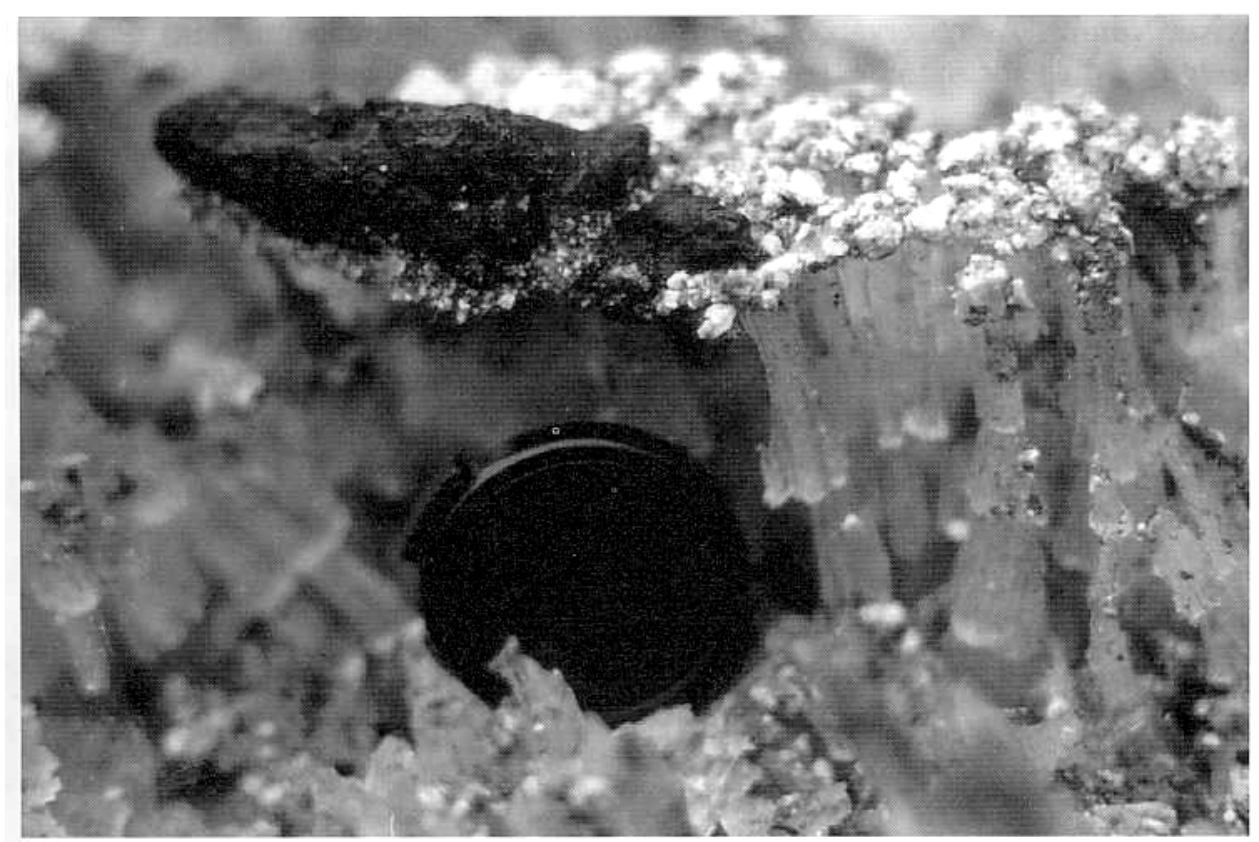

Estampa II - Pipkrakes policíclicos, com cerca de $7 \mathrm{~cm}$ de comprimento e com cobertura de grânulos de feldspato e quartzo (estradão para o Couce, vale do rio Cabril, 850m de altitude, 27/12/94). 
Photo II - Policyclical needle ice with a feldspath and quartz granule cover. 
O crescimento dos pipkrakes perpendicularmente à superfície topográfica (facto que nem sempre se verifica) e o levantamento do material superficial (estampa II), levou à adopção de um modelo que tenta explicar o processo de transporte das partículas na vertente quando aqueles nela se desenvolvem. O modelo adoptado pela generalidade dos autores baseia-se no processo de gelireptação (frost creep). BIROT (1981, p. 304) explica o movimento que uma partícula sofre pela acção de um pipkrake, como sendo igual a h.tg $\alpha$, sendo $\mathrm{h}$ a altura do pipkrake, e $\alpha$ o declive da vertente (fig. 2). Assim, quanto maior o tamanho do pipkrake, e maior o declive da vertente, maior o movimento. A equação apresentada baseia-se, portanto, no pressuposto de que o pipkrake cresce perpendicularmente à vertente, e o movimento se dá, após a fusão, através da acção da gravidade. O autor, citando CORTE, salienta a importância acrescida do declive, variando então o movimento segundo $h \cdot \operatorname{tg}^{2} \alpha$. Conforme BIROT, este aumento no movimento dever-se-ia a um incremento na energia cinética da partícula resultante de uma fusão muito rápida, que originaria a queda mais a jusante.

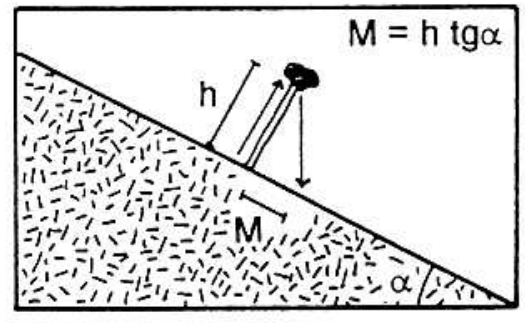

Figura 2 - Movimento causado por pipkrakes por queda gravítica simples (baseado em BIROT, 1981).

Figure 2 - Needle ice induced movement (simple fall).

$\mathrm{Na}$ realidade, o movimento causado por pipkrakes é bastante mais complexo. A relação entre o declive e a taxa de movimento nem sempre é clara (por exemplo PÉREZ em dois artigos - 1987a e 1987c - apresenta conclusões distintas quanto à sua importância).

A ocorrência de pequenos mudflow durante a fusão dos pipkrakes é referida por vários autores (HÖlLERMANN, 1978; PÉREZ, 1987c citando TROLL, 1958, SOONS, 1968 e HigASHI e CORTE, 1971; PÉREZ, 1987c; HARRIS et al., 1993). Estes podem-se associar directamente a um mecanismo de gelifluxão resultante de uma taxa de fusão mais rápida do que o solo possa drenar (PÉREZ, 1987b), que origine uma muito elevada tensão de água intersticial (HARRIS et al., 1993 citando MCROBERTS, 1978 e HARRIS, 1987).

LAWLER (1993, pp. 103-105) esquematizou os mecanismos de erosão ligados à formação de pipkrakes, que intervêm no recuo de margens de cursos de água:

- Queda gravítica de partículas - este mecanismo obedece, grosso modo, ao esquema apresentado por BIROT (1981), embora LAWLER acrescente a hipótese do ângulo de queda da partícula ser intermédio entre a vertical e a perpendicular à vertente. Este facto dever-se-ia a uma contracção do movimento para montante durante a queda. O autor apoia-se em SCHMID (1955), HigASHI e CORTE (1971) e WILLIAMS e SMITH (1989). As observações de campo efectuadas sugerem que este tipo de movimento é mais frequente em pipkrakes com a cobertura não congelada. LAWLER (1993) salienta ainda a hipótese da queda das partículas ser influenciada pelo vento, o que faz com que esta se afaste ainda mais da verticalidade;

- Gotículas com material incorporado - este processo ocorre graças à fusão e concentração de água líquida, que vai transportar em suspensão o material mais fino. 
Pode ocorrer sobre os pipkrakes, no seu interior, ou na sua base, em contacto com o substrato. Deve ser especialmente frequente em episódios de fusão de pipkrakes compactos, associados a precipitação sob forma de chuva;

- Micro-deslizamentos - este mecanismo ocorre quando se dá a fusão basal de conjuntos de pipkrakes, que acabam por perder a base de sustentação e deslizam em pequenos blocos;

- Toppling - consiste na queda de um, ou vários pipkrakes, ficando assim, deitados na vertente. $\mathrm{O}$ autor refere que este processo já tinha sido observado por GRADWELL (1957). A observação deste tipo de mecanismo no Gerês parece indicar que ocorre preferencialmente em pipkrakes cuja base não se encontra congelada e que, quanto à cobertura do solo, sejam do tipo poroso. É um tipo de pipkrakes que geralmente se encontra em equilíbrio instável na vertente.

A monitorização de uma parcela numa vertente, a leste de Lamas do Homem $(1370 \mathrm{~m})$, permitiu identificar outros mecanismos, que ilustram bem a complexidade da acção dos pipkrakes como processo erosivo. As observações foram efectuadas numa parcela de $50 \times 50 \mathrm{~cm}$, delimitada por uma esquadria de madeira, localizada sobre substrato areno-limoso, com elevada percentagem de grânulos à superfície. Os grânulos são monominerais e poliminerais, constituídos fundamentalmente por feldspato e quartzo, provenientes da desagregação do granito. A parcela apresenta um declive de $8^{\circ}$ e uma exposição N180 (Sul) e foi monitorizada verticalmente através de uma sequência fotográfica, englobando o momento sem gelo no solo, com pipkrakes, com pipkrakes em processo de fusão e, finalmente, sem pipkrakes. Foi assim observado um ciclo de gelo-degelo completo entre 12 e 13 de Fevereiro de 1994.

Na primeira observação efectuada de manhã (7.45h), ainda sem radiação solar, foi possível verificar a presença de pipkrakes com $2 \mathrm{~cm}$ de comprimento, limpos, e com uma cobertura de grânulos não congelados. Os pipkrakes cobriam completamente o solo, excepto sob a esquadria de madeira, que isolou o solo, não deixando progredir a frente de congelação. Deduz-se portanto que, durante a noite, tenha havido uma penetração da frente de congelação no solo até à base do nível de grânulos, onde terá estabilizado, dando-se início à segregação de gelo.

Progressivamente, à medida que o Sol subia no horizonte, e com o aumento da temperatura, foi-se dando a fusão dos pipkrakes. Estes derreteram de forma heterogénea, sem obedecer a qualquer padrão detectável, o que originou o aparecimento de pequenas depressões centimétricas disseminadas na parcela, que denominei por micro-alvéolos de fusão. Estes foram aumentando progressivamente, tendo coalescido e, finalmente, desaparecido, pela fusão da totalidade dos pipkrakes no final da manhã.

A observação directa no campo e a posterior comparação sequencial das fotografias permitiu a observação de um fenómeno curioso. $\mathrm{O}$ movimento dos grânulos era fortemente influenciado pela sua posição em relação aos microalvéolos de fusão. Os grânulos tendiam assim a cair para dentro daqueles. Desta forma o movimento observado nem sempre era em direcção à base da vertente, mas resultava de micro-declives frequentemente opostos ao sentido de inclinação da vertente, originados pelos próprios pipkrakes. Os grânulos deslocavam-se assim em direcções diversas, tendo sido mesmo observados grânulos que subiram um pouco na vertente na vertente segundo o mecanismo apresentado na figura 3. Naturalmente, este mecanismo terá especial incidência em vertentes de declive fraco. As implicações que apresenta são importantes, especialmente por ilustrarem a complexidade deste processo erosivo. Provavelmente uma cuidada monitorização do processo, poderá dar a conhecer outros mecanismos de transporte de material pela acção de pipkrakes. 

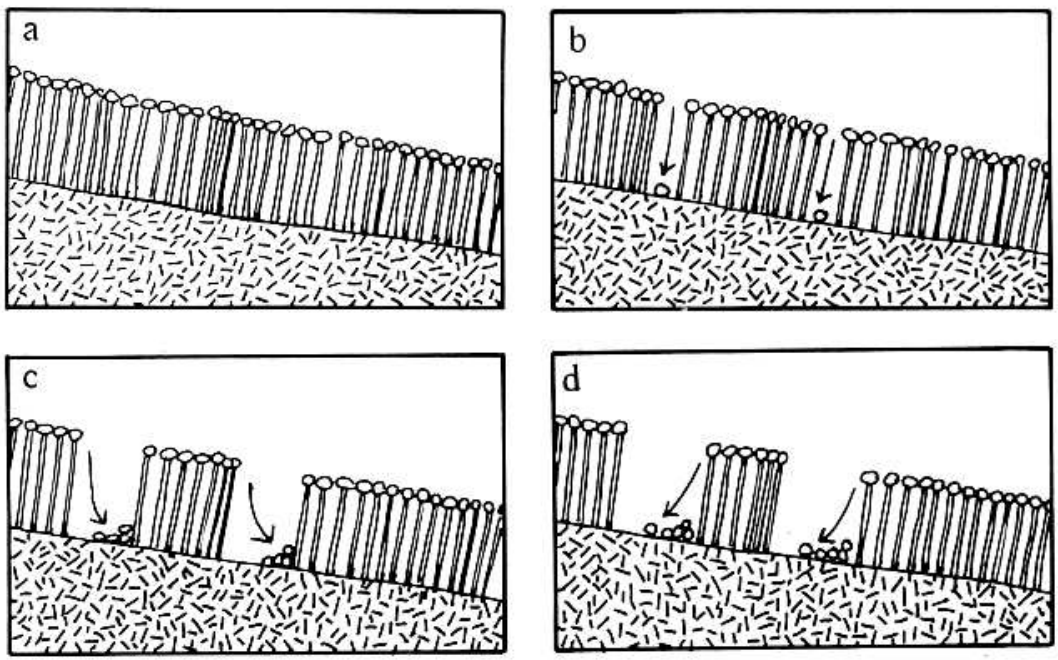

Figura 3 - Movimento de grânulos por pipkrakes, associado ao aparecimento de micro-alvéolos de fusão. a) Pipkrakes porosos levantando uma cobertura contínua de grânulos não congelados; b) Início da fusão dos pipkrakes em lugares irregularmente espaçados e queda directa dos grânulos, sem movimento na vertente; c) fusão dos pipkrakes e movimento dos grânulos controlado pela posição destes em relação ao micro-alvéolo; d) a formação de aclives possibilita uma pequena subida dos grânulos na vertente.

Figure 3 - Needle ice induced movement associated with the formation of melting gaps.

A observação da rosa de movimentos de alguns grânulos na mesma parcela (fig. 4), mostra uma tendência para estes se movimentarem para SE e não directamente em direcção à base da vertente segundo o maior declive ${ }^{3}$. Este facto pode estar relacionado com o ângulo de incidência dos raios solares durante a manhã, implicando a fusão dos pipkrakes preferencialmente nessa direcção. A perda da base de sustentação dar-se-ia então preferencialmente do quadrante SE.

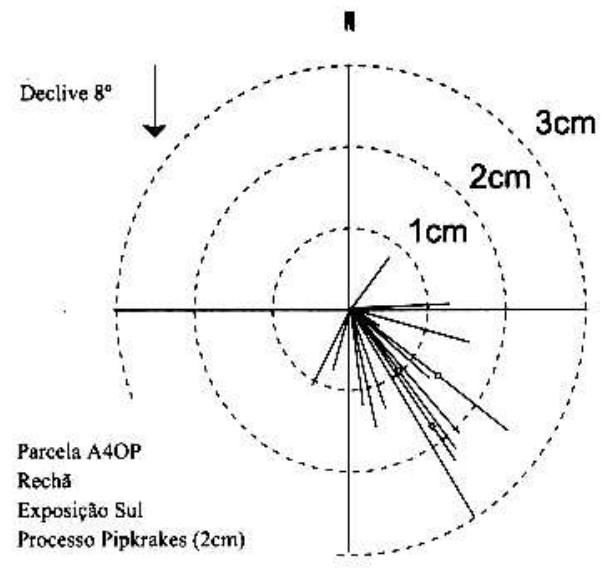

Figura 4 - Movimento de 18 grânulos num ciclo gelo-degelo (12/2/94 - 13/2/94).

Figure 4 - Needle ice induced movement of 18 granules in a freeze-thaw cycle.

\footnotetext{
3 A obtenção da rosa de movimentos fez-se através da comparação de duas fotografias, uma anterior ao episódio de formação de pipkrakes e outra, posterior à sua fusão. Este método apresenta algumas limitações resultantes de distorções angulares resultantes das posições em que foram obtidas as fotografias. A utilização de uma esquadria como referência reduz os erros, embora não os anule. Tentei ainda reduzir as distorções pelo tratamento das imagens por computador. De qualquer forma, poderá existir algum erro no movimento medido, o qual será menor para as direcções.
} 


\section{2 - Mecanismos indirectos}

A observação de taludes antrópicos em depósitos heterométricos realçou a importância que os pipkrakes apresentam na remoção de calhaus de grandes dimensões.

A formação de pipkrakes é muito frequente em cortes antrópicos, especialmente em granitos alterados e depósitos de material granítico, com abundante matriz silto-argilosa (por exemplo, ao longo do estradão dos Carris). Verifica-se nesses locais um recuo paralelo da parte mais declivosa do talude, uma vez que o material mais fino, ao ser levantado por pipkrakes, cai directamente para a base do corte, durante a fusão. Este recuo do talude vai deixar salientes os calhaus com fraco grau de alteração que se encontram no depósito de vertente. Com a sucessão de ciclos de gelo-degelo os referidos calhaus acabam por perder a base de sustentação, caindo até à base do talude.

Em blocos de maior dimensão, à instabilização causada pela diminuição do apoio basal, por vezes acrescenta-se uma acumulação no seu topo, de material removido da vertente. Assim, para além da perda de base de sustentação, o bloco vai sofrer uma força vertical resultante do aumento de peso sobre ele, o que pode facilitar o seu desprendimento do talude e movimentação na vertente (fig. 5).
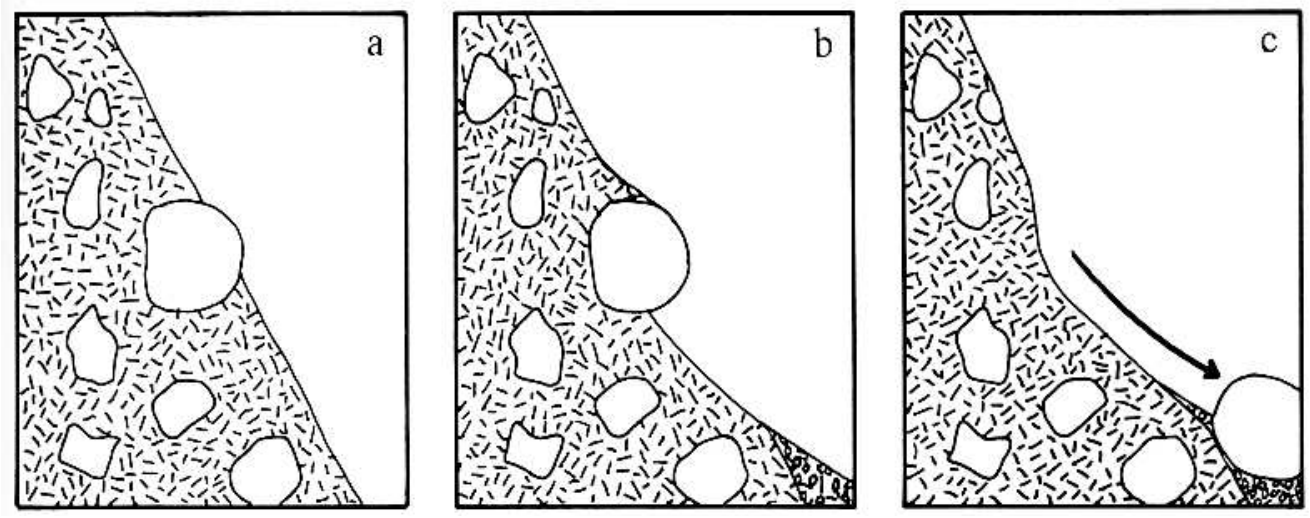

Figura 5 - Queda de calhaus pela acção de pipkrakes em depósitos heterométricos. a) corte antrópico expondo o depósito; b) a erosão por pipkrakes faz com que o corte recue paralelamente a si próprio, o que provoca a remoção de material na base do bloco, ficando no entanto material no seu topo; c) a perda do suporte basal provoca a queda do bloco.

Figure 5 - Needle ice induced cobble fall in an heterometric slope deposit.

\section{4 - MICROFORMAS ORIGINADAS PELA ACÇÃO DOS PIPKRAKES NA SERRA DO GERÊS}

A importância dos pipkrakes como agente morfogenético é reconhecida pela generalidade dos autores (FrENCH, 1976; WASHBURN, 1979; PÉREZ, 1987a, 1992a, 1992b). As formas originadas pela sua actividade são sempre de pequena dimensão, embora possam afectar áreas extensas. A ocorrência de microformas originadas por pipkrakes depende fundamentalmente de três factores: a existência de um substrato pouco coerente que possibilite a sua formação; condições climáticas e especialmente microclimáticas que proporcionem uma elevada frequência de situações propícias à formação de pipkrakes; e finalmente, não existir qualquer outro processo erosivo que destrua a micromorfologia por eles originada. Embora as duas primeiras condições sejam fundamentais, é a última que é decisiva para a manutenção da micromorfologia, facto especialmente importante nas áreas onde os pipkrakes não são o principal agente morfogenético, como é o caso da Serra do Gerês, onde a erosão hídrica parece dominar. 


\section{$4.1-$ Nubbins}

Nubbins são pequenos aglomerados de terra, com um diâmetro de um a vários centímetros (WASHBURN, 1979, p. 94). Têm sido descritos por vários autores, como resultantes da acção dos pipkrakes (HAGEDORN, 1974, p. 36; FRENCH, 1976, p. 33 citando Troll, 1958 e FAHEY, 1973; FurRe, 1954, 1955, HeINE, 1977, MoHAUPT, 1932, FRITZ MÜLLER, 1954, TROLL, 1944, 1958, citados por WASHBURN, 1979, p. 95; HÖLLERMAN, 1978, p. 99).

$\mathrm{Na}$ área estudada é frequente a observação de nubbins em períodos com formação de pipkrakes. Sendo pequenos aglomerados, são facilmente desagregados pela acção da escorrência, rainsplash e vento, o que os torna efémeros e apenas ligados a períodos secos e frios, normalmente anticiclónicos, como se verá.

Uma vez que os nubbins são pequenos agregados de material pouco coerente, a sua formação é influenciada pelas características granulométricas do substrato. Parece verificar-se um mais frequente aparecimento de nubbins onde a fracção silto-argilosa é significativa, de modo a que as partículas do solo se possam agregar. É o que sucede em alguns microtaludes onde os nubbins são mais frequentes. Nos locais onde há uma camada superficial de grânulos sobre material mais fino, a ocorrência de pipkrakes dá origem a uma superfície de aspecto pouco coerente e desagregado. Observa-se neste caso o aparecimento de pequenos "buracos" isolando os grânulos superficiais.

\section{2 - Solos estriados incipientes}

O papel dos pipkrakes na formação de solos estriados tem sido sublinhado por vários autores (HÖLLERMAN, 1978; PÉREZ, 1992a).

Os pipkrakes podem originar solos estriados calibrados e solos estriados não calibrados. Os primeiros são frequentes nas regiões periglaciárias onde os pipkrakes apresentam uma elevada frequência de ocorrência, onde há depósitos relativamente heterométricos e onde nenhum outro processo erosivo tenha um papel morfogenético mais activo, o que destruiria as estrias do solo.

Foram observados na Serra do Gerês esboços muito incipientes de solos estriados em alterito granítico. Não foi efectuada qualquer análise granulométrica às referidas estrias, no entanto as observações de campo apontam para que não se verifique uma calibragem lateral do material. Segundo Höllerman (1978, p. 94) e PérEZ (1992a, p. 130), num solo estriado não calibrado, as estreitas bandas de partículas estão alinhadas, não no sentido do maior declive, mas na direcção dos raios de sol matinais. Os poucos casos de solo estriado incipiente observados não confirmam esta afirmação. Parece verificar-se um alinhamento no sentido do maior declive, embora, por vezes, se apresente obliquamente a este. É de salientar que o vento pode ter um papel importante na elaboração das estrias, como é salientado por Troll (1944), citado por WASHBURN (1979, p. 93), BEATY (1974) e HALL (1979).

$\mathrm{O}$ aspecto extremamente incipiente, bem como o carácter pontual dos solos estriados observados no Gerês, parecem indicar tratar-se de uma forma efémera, rapidamente desmantelada pela erosão hídrica.

\section{3 - Buracos em volta de pedras (Gaps around stones)}

É frequente observar-se na Serra do Gerês, especialmente após alguns dias com formação de pipkrakes, a presença de pequenos buracos rodeando calhaus. Este facto é também referido por HAGEDORN (1974, p. 36), WASHBURN (1979, p. 95), JENNINGS (1983, p. 330) e MARQUES et al. (1990, p. 167). Segundo WASHBURN (1979, p. 95), 
os buracos devem-se aos calhaus de maior dimensão serem suficientemente grandes para não serem levantados pelas agulhas ou empurrados pelo material adjacente no ínicio da congelação. Isto, especialmente, se estiverem parcialmente enterrados, ficando ancorados ao solo por congelação in situ. A fusão e o consequente movimento descendente dos grânulos envolventes, faria com que estes se afastassem progressivamente dos calhaus. JENNINGS (1983, p. 330) propõe uma génese semelhante, acrescentando a hipótese de uma maior absorção de radiação pelas pedras situadas em posição deprimida, que causaria a fusão mais rápida dos pipkrakes situados próximo delas, sendo então as partículas afastadas do calhau por lavagem.

\section{4 - Obstáculos rochosos (Rock dams)}

Em vertentes de acentuado declive, os blocos de grande dimensão ou os troncos, podem gerar uma travagem na deslocação do material, provocando a acumulação a montante. A jusante do obstáculo, a continuada erosão causa a migração do material, originando aí uma depressão. Este mecanismo foi estudado em detalhe por PÉREZ (1987a). Segundo este autor, os blocos são designados por rock dams, bremsteine (PÉREZ, 1987a, p. 40, citando HeINE, 1977) ou blocs freineurs (PÉREZ, 1987a, p. 40, citando FRANCOU, 1986). Há no entanto que as interpretar com especial cuidado, uma vez que podem resultar de uma convergência morfológica, por exemplo, pela acção das águas de escorrência.

Não tive oportunidade de observar a acção de obstáculos rochosos em vertentes naturais cuja acumulação se possa relacionar com a acção dos pipkrakes, apenas surgindo estes, em cortes antrópicos em depósitos de vertente muito heterométricos. Foi observada, em alguns casos, uma acumulação de material no topo de blocos em cortes antrópicos, bem como uma clara falta de suporte basal. Por vezes, a área abaixo do bloco, limpa do material grosseiro, apresenta uma forma alongada no sentido do declive, denominada fine-earth flag (HASTENRATH, 1973; PÉREZ, 1987a, p. 40 citando HEINE, 1977). Nos casos observados, a fine-earth flag não apresentava uma típica forma alongada, facto que se pode dever à existência de vegetação a jusante que produzia uma nova barreira à migração do material no corte.

\section{5 - Marmitas criogénicas (Needle ice pan)}

As marmitas criogénicas são pequenas depressões aproximadamente circulares, com cerca de 1 a $5 \mathrm{~m}$ de diâmetro. Apresentam um rebordo bem marcado de cerca de 20 a 40 cm de altura, que evolui por desagregação (HASTENRATH, 1977, p. 358; PÉREZ, 1992b, p. 87). Estas depressões surgem em áreas de acumulação de material, geralmente com bastante matéria orgânica ou turfa, e com uma cobertura contínua de vegetação rasteira (geralmente herbáceas). O rebordo da depressão evolui principalmente pela acção dos pipkrakes, recuando e ampliando a depressão. Uma vez que o coberto vegetal é contínuo na área que envolve a marmita, a acção dos pipkrakes apenas incide nas áreas expostas do rebordo, sendo especialmente activos os locais onde a densidade de raízes é menor.

Foram identificadas formas deste tipo no Vale do Couce, próximo da Lagoa do Marinho. Embora os pipkrakes pareçam desempenhar um importante papel no recuo dos rebordos da marmita, para que esta se inicie, deverá ser importante o pisoteio antrópico, ou do gado. Não é de afastar a hipótese das marmitas terem inicio através de um processo de piping, com consequente subsidência.

O rebordo pode ainda evoluir pela acção da humidificação/dessecação, pelo rainsplash e por erosão eólica. Esta última parece ter um importante papel na remoção 
do material desagregado (PÉREZ, 1992b), facto também por nós notado (VIEIRA, 1995, p. 106).

\section{6 - Microtaludes em cortes antrópicos}

A importância da actividade dos pipkrakes nos cortes antrópicos foi salientada por ARNAÉZ VADILlo (1983) para a Sierra de la Demanda (Espanha) e PEDROSA (1993) para a Serra do Marão. Na Serra do Gerês estes cortes mostram também uma actividade criológica notável, embora seja importante considerar casos de convergência morfológica, pela acção da humidificação-dessecação na desagregação dos cortes.

A incidência dos pipkrakes nos cortes antrópicos provoca um recuo paralelo deste que, do ponto de vista morfológico, se torna notório pela acumulação de material na base, formando um microtalude (estampa III). Este pode ser mais ou menos contínuo ao longo do corte, consoante os locais de incidência dos pipkrakes. Assim, num corte talhado em granito homogeneamente alterado e sem cobertura vegetal, verifica-se o aparecimento de um microtalude ao longo de toda a base do corte. Num corte protegido por vegetação, os pipkrakes apenas se formam nos sectores nus, embora seja possível, em sectores cobertos por musgos, que a fina protecção, por eles constituída, se rompa, causando a degradação do corte. Se a área de formação de pipkrakes no corte for pouco extensa (por diferenças granulométricas, de humidade, ou na cobertura vegetal), formam-se pequenos cones basais de material desagregado.

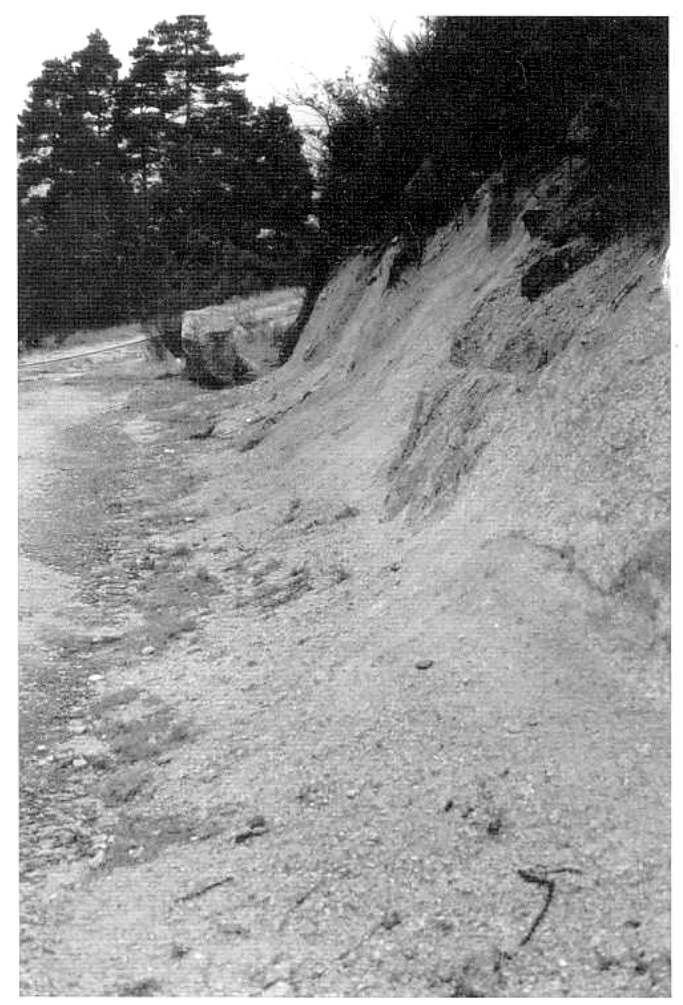

Estampa III - Microtalude em corte antrópico afectando granito alterado. A acumulação basal resulta da acumulação de material desagregado por pipkrakes (Portela do Homem, 750m de altitude, 15/2/94).

Photo III - Microtalus in weathered road cut. 
Os microtaludes referidos são muito frequentes na base dos cortes, não só em granito alterado, mas também em depósitos de vertente heterométricos. A sua formação parece ser relativamente rápida, uma vez que em períodos de precipitação mais intensa e concentrada são facilmente removidos.

A observação de cortes em granito alterado mostra existir uma camada milimétrica de material, que é removida do corte e que se acumula no talude em cada ciclo de formação de pipkrakes. A rapidez da génese destas formas pode-se também apreciar pela acumulação de material desagregado sobre vegetação ainda verde (estampa IV), bem como em áreas com acumulação de neve, onde parte do corte se encontra exposto, acumulando-se o material desagregado sobre a neve.

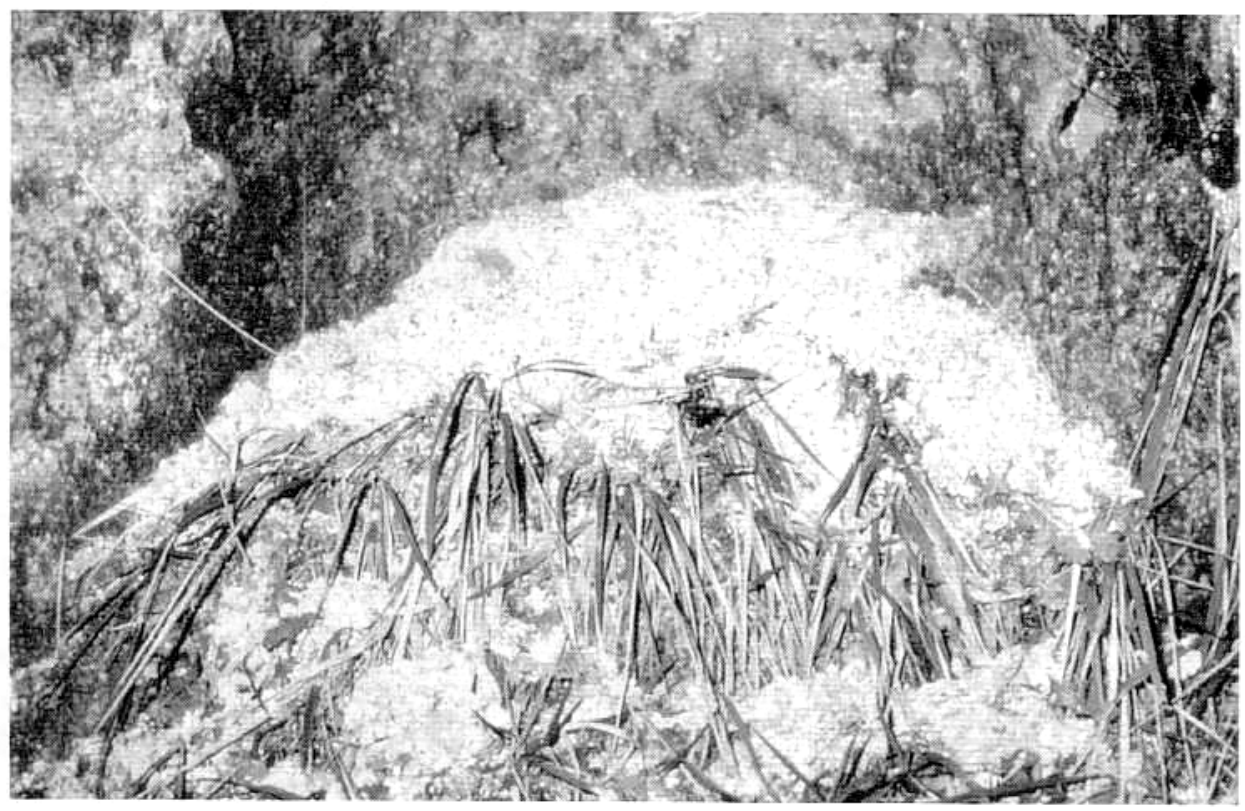

Estampa IV - Material desagregado cobrindo vegetação ainda verde, o que ilustra a velocidade de desagregação dos cortes antrópicos pela acção dos pipkrakes (estradão Portela do Homem, 760m de altitude, 12/2/94).

Photo IV - Vegetation covered by desegregated granite showing the speed of needle ice induced erosion.

\section{7 - Microtaludes em margens de barrancos}

Com uma génese semelhante à dos microtaludes acima descritos, este tipo de microtaludes apresenta geralmente um papel mais importante no balanço erosivo, uma vez que o material se acumula directamente no canal de escoamento, sendo prontamente removido, com um ligeiro aumento do caudal.

Este tipo de microtaludes surge geralmente nas margens de barrancos entalhados em material móvel, o qual na área estudada é constituído fundamentalmente por areias graníticas e matéria orgânica. O recuo das margens de turfeiras (as presentes no Gerês são muito incipientes) através da sua desagregação, foi estudado por PÉREZ (1992b) e é conhecido por turf exfoliation ou Rasenabschälung. LAWLER (1985, 1987, 1993) estudou detalhadamente a influência dos pipkrakes no recuo das margens de pequenos cursos de água, os quais parecem evoluir por um processo semelhante.

Os pipkrakes podem ter ainda um papel significativo no desenvolvimento de outras microformas (microfiguração de solos, etc), as quais não são descritas, por não terem sido observadas na área estudada. 


\section{5 - ALGUMAS SITUAÇÕES ATMOSFÉRICAS RESPONSÁVEIS PELA FORMAÇÃO DE PIPKRAKES NA SERRA DO GERÊS}

Vários autores têm salientado a necessidade de um céu limpo e calma atmosférica, para que se dê a formação de pipkrakes (GEIGER, 1980; SOONS e GREENLAND, 1970; OutCAlT, 1971; ARNAEZ VADILlO, 1983, 1987). De facto, as situações em que observei pipkrakes na Serra do Gerês foram todas elas anticiclónicas. Mas foram observações pontuais, pelo que tal não significa que os pipkrakes sejam exclusivos dessas situações.

$\mathrm{Na}$ região em que foi efectuado o presente estudo, as situações anticiclónicas, principalmente as invernais, parecem ser as únicas capazes de provocar um acentuado arrefecimento do solo até à congelação. É portanto possível que seja esta a razão de uma coincidência entre as noites anticiclónicas e a formação de pipkrakes. É também possível que, em regiões mais frias, se possam formar pipkrakes em situações de céu nublado, mas sem chuva e com temperaturas do ar ligeiramente negativas.

Foram efectuadas três campanhas de campo em episódios com formação de pipkrakes, tendo ocorrido todos eles, como se disse, em situações anticiclónicas de Inverno (fig. 6). O comportamento térmico das estações climatológicas portuguesas, em abrigo, que normalmente resulta das várias situações anticiclónicas de estação fria, fizeram-me inicialmente pensar que a ocorrência de pipkrakes estaria limitada aos episódios mais frios, com fluxo de norte ou nordeste. Tal hipótese não se confirmou. Como se pode verificar (fig. 6), as situações meteorológicas com formação de pipkrakes na Serra do Gerês, apesar de anticiclónicas, foram variadas. Houve mesmo formação de pipkrakes na área do Outeiro do Pássaro com um anticiclone ibero-mediterrâneo a influenciar a Península Ibérica (4/2/95), com vento local de S a SE e uma velocidade média, a $1,5 \mathrm{~m}$ do solo, de 0,1 a $2,5 \mathrm{~m} / \mathrm{s}$, consoante os pontos do perfil climático efectuado. Então, de madrugada, com uma temperatura do ar, a 1,5m de altura, de cerca de $+8^{\circ} /+9^{\circ} \mathrm{C}$, foi possivel observar o solo gelado, com pipkrakes.
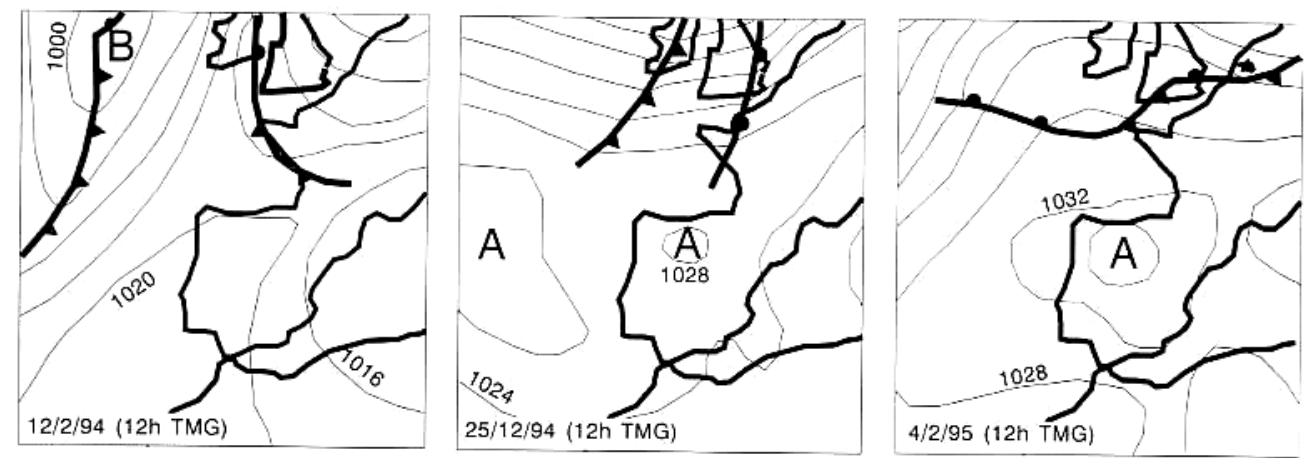

Figura 6 - Situações meteorológicas correspondentes às observações de pipkrakes na Serra do Gerês (Fonte: Boletin Meteorologico diario, Madrid).

Figure 6 - Meteorological situations associated with needle ice formation in the Serra do Gerês.

Foi possível verificar que, nos episódios anticiclónicos mais frios e prolongados, de que faz parte o dia 25/12/94, os pipkrakes se apresentaram mais desenvolvidos, tanto em área ocupada como em comprimento. Foi frequente nessa campanha observar pipkrakes policíclicos, sem fusão total diária. No episódio anticiclónico de 4/2/95, atrás referido, o desenvolvimento das agulhas de gelo era menor, apenas surgindo exemplos de pipkrakes policíclicos em lugares que se mantiveram à sombra durante quase todo o dia. É mesmo possível que se verifique uma diferente eficácia 
morfogenética consoante a situação meteorológica, sendo mais frequentes os ciclos de gelo-degelo no solo em episódios com fluxo meridional, e menos frequentes com fluxos de norte, ou continentais, situações estas em que os pipkrakes podem permanecer mais tempo no solo, especialmente se a radiação solar directa for fraca após a sua formação. Esta é uma hipótese que carece ainda de mais observações práticas. Parece, deste modo, que a formação de pipkrakes pode ser relativamente frequente nas áreas mais elevadas do Gerês, especialmente nos meses de Inverno, uma vez que a ocorrência de períodos anticiclónicos está longe de ser excepcional durante os meses da estação fria (RAMOS, 1987, p. 34). As variações interanuais podem ser grandes, sendo difícil estabelecer, mesmo aproximadamente, sem estudos mais detalhados, o número de dias com ocorrência de pipkrakes nas montanhas do Noroeste português. A isto, há ainda que acrescer as irregularidades microclimáticas induzidas pela topografia, que complicam bastante os padrões térmicos em períodos frios anticiclónicos sem vento.

\section{6 - PAPEL MORFOGENÉTICO DOS PIPKRAKES NA SERRA DO GERÊS}

A ocorrência de pipkrakes está naturalmente circunscrita às áreas onde existe um substrato pouco coerente. Na Serra do Gerês estas áreas encontram-se fundamentalmente no andar das areias graníticas (COUDÉ-GAUSSEN, 1981). Nos sectores cimeiros e vertentes, as acumulações de sedimentos "finos" são muito limitadas, facto que resulta não só da erosão glaciária quaternária, mas também da erosão actual do material mais fino. Assim, nessas áreas, os depósitos mais espessos encontram-se em pequenas depressões de dimensão decamétrica a hectométrica, em posição topográfica variável. É ainda possível encontrar material mobilizável por pipkrakes em depósitos coluviais com abundante matriz silto-argilosa, que se concentram fundamentalmente na base das vertentes.

As áreas referidas são no entanto aquelas onde o coberto vegetal apresenta um maior desenvolvimento, pelo que apenas vão surgir condições para a formação de pipkrakes em cortes antrópicos (geralmente associados à abertura de estradões), em barrancos, ou em depósitos nas áreas onde o escoamento ou a dinâmica eólica sejam especialmente activos. $\mathrm{O}$ homem surge assim como um agente muito importante na activação da dinâmica dos pipkrakes, como referem ARNÁEZ VADILlo (1983) e PEDROSA (1993).

Embora o coberto vegetal seja um factor condicionante para o crescimento de pipkrakes, a ocorrência destes pode danificar a vegetação. Esta destruição dá-se principalmente ao nível das estruturas radiculares que se podem partir, ou ficar desenterradas.

\section{1 - Barrancos e pequenos cursos de água}

É provavelmente no recuo das margens de barrancos e de pequenos cursos de água, que a erosão por pipkrakes é mais eficaz. O material que é desagregado das margens abruptas, vai acumular-se na sua base, sendo posteriormente transportado pelas águas de escorrência, durante, ou após períodos de precipitação intensa.

Existem dois tipos de barranco nos quais a acção dos pipkrakes parece especialmente eficaz: os barrancos entalhados nas bacias de acumulação de altitude; e os barrancos entalhados em areias graníticas e depósitos de vertente.

O primeiro tipo de barranco é frequente nas bacias de acumulação de altitude, que apresentam frequentemente um coberto vegetal herbáceo e arbustivo. São barrancos pouco amplos, não ultrapassando na maior parte dos casos 1 a $2 \mathrm{~m}$ de largura, com um 
rebordo de cerca $50 \mathrm{~cm}$ a $1 \mathrm{~m}$ de altura. Este rebordo está talhado em material areno-limoso envolvido em abundante matéria orgânica e raízes, o que faz com que se apresente relativamente coerente, originando um acentuado declive. A origem destes entalhes está relacionada com uma descida do nível de base local das pequenas depressões, que pode ter origem numa ruptura de material que a jusante tivesse um efeito de barreira, ou numa ruptura no coberto vegetal devido a incêndios e/ou pastoreio. Outra hipótese para a sua existência, é uma contínua migração lateral do canal que permita a acumulação nas áreas abandonadas. Essa acumulação manteria o enchimento da depressão.

A formação de pipkrakes faz recuar a vertente do barranco, deixando geralmente suspenso o sector superior, suportado por raízes, e onde a acção dos pipkrakes é mitigada. O progressivo recuo da vertente, acaba por provocar a queda da parte superior por falta de base de apoio.

$\mathrm{O}$ segundo tipo de barrancos apresenta geralmente um perfil transversal em V, sendo as dimensões semelhantes ao primeiro. Surgem entalhados em areias graníticas in situ ou em depósito. Estão normalmente associados à degradação antrópica do coberto vegetal. São por isso frequentes próximo de estradões, por vezes entalhando-os, ou afectando os cortes antrópicos. O perfil em $\mathrm{V}$ tem origem na menor coesão do material, na erosão linear e na acção da escorrência sobre as margens. O declive da área afectada é um factor importante, sendo normalmente mais acentuado neste tipo de barrancos do que no anterior.

Em episódios meteorológicos de frio intenso, a água pode gelar no interior de alguns barrancos, promovendo o movimento por deslizamento superficial das partículas que nele caem.

Embora os pipkrakes desempenhem um papel importante no recuo das margens dos barrancos, estes são, naturalmente, de origem essencialmente hídrica.

\section{2 - Cortes antrópicos e estradões}

Ao construir estradões e ao efectuar cortes nas vertentes, o homem destrói a cobertura vegetal, deixando o substrato exposto à erosão.

No que se refere à acção dos pipkrakes, os cortes antrópicos podem-se dividir em dois tipos principais: os talhados em granito alterado; e os talhados em depósito de vertente, com ou sem solo associado. Ambos apresentam um sector de alimentação de declive acentuado, e um microtalude basal. O sector superior recua paralelamente a si próprio, uma vez que a acção dos pipkrakes vai provocar a desagregação do material e, consequentemente, a queda pela acção da gravidade. $\mathrm{O}$ microtalude é principalmente um sector de acumulação, embora também seja afectado por pipkrakes, que causam a migração do material para a base. Se não existir qualquer barreira natural na base (a vegetação ou um bloco), o microtalude é erodido na base através da acção de sapa da água, que escoa muitas vezes canalizada no contacto do corte com o estradão.

Os cortes em granito alterado in situ, evoluem de forma homogénea, formando um microtalude homométrico.

Os cortes em depósitos de vertente heterométricos, especialmente quando os clastos não se encontram muito alterados, podem evoluir de modo brusco. Enquanto a matriz do depósito se desagrega em cada ciclo diário, isso não acontece aos clastos, que vão ficando progressivamente mais salientes no corte, até caírem por perda da base de sustentação. Esta queda é brusca, dependendo o movimento do calhau da sua dimensão, do perfil do corte e da vegetação a jusante. 
A monitorização de um corte num depósito de vertente bastante heterométrico na estrada Caldas do Gerês - Portela do Homem, próximo do rio do Vidos (alt. aprox. $800 \mathrm{~m}$ ), confirmou este tipo de evolução. Foi observado o desabamento de dois calhaus de granito, sendo um travado pela vegetação da base do corte, e outro deslocando-se até à estrada.

A exposição do corte, bem como o efeito de sombra causado pela vegetação arbórea e montanhas próximas, faz com que o corte no final de Dezembro apenas receba radiação solar directa durante cerca de 1 hora, à tarde. É assim possível a manutenção dos pipkrakes de um dia para o outro, especialmente dos formados no microtalude. O número de ciclos de formação-fusão de pipkrakes parece ser maior no sector superior do corte. Ali os pipkrakes eram de menor dimensão (3 a $5 \mathrm{~cm})$ e a acção da gravidade tornava-os mais instáveis. A maior circulação do ar no sector superior do corte (desprovido de vegetação) poderá ser também importante para uma fusão mais rápida. É ainda de considerar o papel do vento na dessecação da camada superficial do corte, bem como a acumulação de água que se verifica no sector basal do corte (resultante da desagregação do material do corte, que funciona como esponja, sendo também de considerar o fornecimento de água proveniente da fusão dos pipkrakes do sector superior do corte), para as diferenciações de tamanho dos pipkrakes observados -3 a $5 \mathrm{~cm}$ no sector superior e cerca de $7 \mathrm{~cm}$ no microtalude.

Foi ainda efectuada a monitorização do movimento do material do microtalude desde a formação dos pipkrakes até à sua fusão ${ }^{4}$. Sem perturbar a organização do depósito, foram pintadas três linhas rectas no solo, utilizando tinta vermelha em spray e uma folha de acetato cortada para o efeito. Após a fusão, usando uma outra folha de acetato transparente, reproduziram-se as linhas inicialmente pintadas. Foi assim possível, com uma intervenção mínima, medir o movimento verificado. O sector monitorizado apresentava um declive de $28^{\circ}$ e pipkrakes com $7 \mathrm{~cm}$ de comprimento. Se usarmos a fórmula referida por BIROT (1981, p. 304) a despeito das suas limitações, o movimento previsto seria, em média, de $3,3 \mathrm{~cm}$. O movimento observado não foi uniforme, facto que se pode dever à heterogeneidade do material, mas também a poderem intervir conjuntamente diferentes mecanismos durante o processo de fusão. Assim, como se pode observar na figura 7, o movimento entre os dias 26 e $28^{5}$ variou entre 4,5 e $0,3 \mathrm{~cm}$, o que denota uma grande irregularidade no movimento. Parece também notar-se uma diminuição deste mais próximo da base.

\footnotetext{
${ }^{4}$ Infelizmente ao iniciar a observação os pipkrakes já estavam formados. Esta é, aliás, uma das dificuldades de monitorização, uma vez que se torna necessário, antes de esta ter início, prever os locais onde se irão formar pipkrakes.

5 Não houve fusão no dia 26 , nem condições para a formação após esta data.
} 

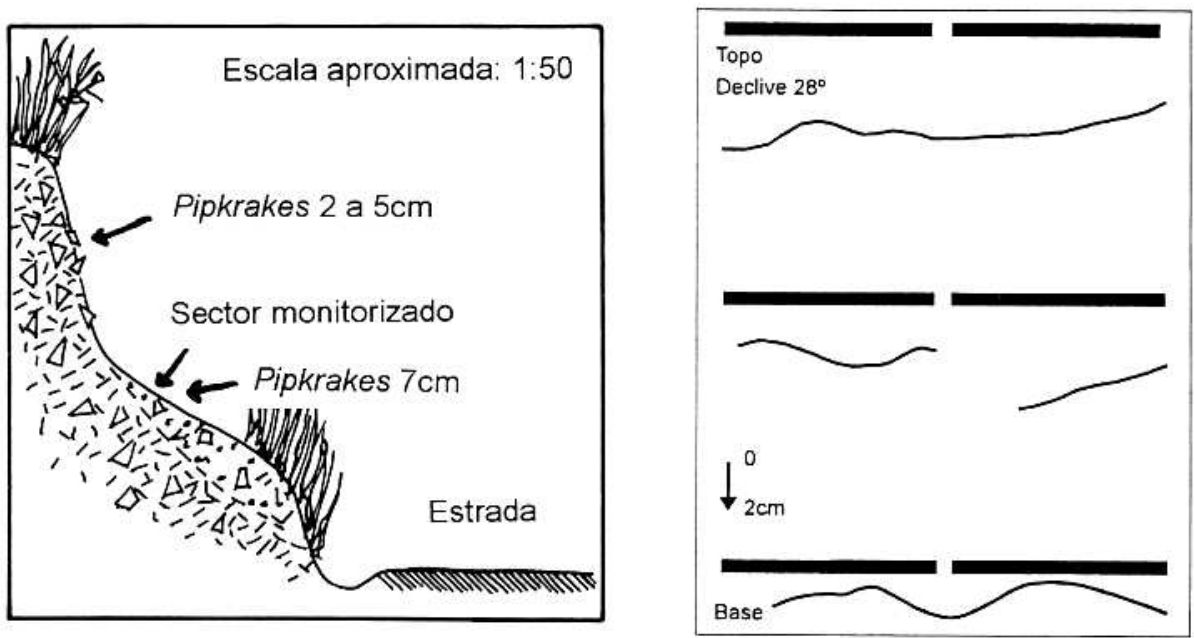

Figura 7 - Movimento das linhas pintadas no microtalude de um corte na estrada Caldas do Gerês - Portela do Homem, próximo do rio dos Vidos. As bandas rectilíneas representam a posição inicial das partículas levantadas por pipkrakes com $7 \mathrm{~cm}$ de comprimento (26/12/94); as linhas curvas representam a posição das partículas, após a fusão dos pipkrakes (28/12/94). Entre as duas observações não houve condições para a formação de novos pipkrakes.

Figure 7 - Movement of painted lines in a microtalus in a road cut between Caldas do Gerês and Portela do Homem.

O material levantado por pipkrakes no microtalude, com base em três amostras, variava entre 12,5 e $13,5 \mathrm{~kg} . \mathrm{m}^{-2}$. É de referir que as agulhas apresentavam uma cobertura de material muito heterogénea, que atingia $1 \mathrm{~cm}$ de espessura.

Os estradões de terra batida são áreas muito favoráveis à formação de pipkrakes (não só na rodovia, mas também nos cortes antrópicos que os limitam), que os cobrem em períodos mais frios, de forma mais ou menos contínua (o mesmo observou ARNAÉZ VADILLO, 1983). Os pipkrakes parecem ser aí especialmente importantes na remobilização do material desagregado, facilitando o seu transporte por erosão hídrica (escoamento superficial) e eólica. É difícil calcular, mesmo de forma aproximada, a importância dos pipkrakes naquelas áreas, uma vez que o declive, granulometria e teor em humidade são muito diversos, variando por isso também a intensidade daquele processo de erosão. Não restam no entanto dúvidas para poder afirmar que é nos estradões que os pipkrakes apresentam uma cobertura mais significativa. Assim, considerando os muitos quilómetros deste tipo de rodovia existentes na serra, a quantidade de material levantado e deslocado por ciclo, deverá ser muito grande.

\section{3 - Áreas de acumulação de material grosseiro}

As áreas que possuem rególito com fraco coberto vegetal, são geralmente áreas de declive suave, nos sectores mais elevados da serra. Apresentam um escoamento superficial bastante activo (embora sem incisão linear), uma erosão eólica importante, e um pastoreio significativo.

A cobertura de pipkrakes nestas áreas é normalmente descontínua, uma vez que são depósitos lateralmente heterogéneos e com diferentes susceptibilidades à segregação de gelo. É muito difícil calcular o contributo dos pipkrakes para a erosão nessas áreas, uma vez que são muitos os processos erosivos activos ao mesmo tempo. $\mathrm{O}$ declive suave reduz naturalmente as taxas de movimento pela acção directa dos pipkrakes, e estes parecem ser especialmente importantes na mobilização da camada superior do solo, facilitando assim a erosão eólica e hídrica. 
São áreas em que o solo apresenta normalmente uma película superficial de grânulos, o que leva especialmente à formação de pipkrakes com cobertura não congelada (conforme a classificação apresentada em VIEIRA, 1995, p. 99), sendo portanto o principal mecanismo de erosão, resultante da fusão, a queda gravítica da cobertura.

\section{CONCLUSÃO}

O estudo efectuado na Serra do Gerês permitiu dar novas achegas quanto à actividade morfogenética dos pipkrakes, processo que ainda não tinha merecido um estudo relativamente aprofundado em Portugal.

A acção dos pipkrakes como processo morfogenético é difícil de quantificar, embora apresente claramente uma elevada capacidade erosiva. A sua ocorrência parece relacionada com períodos frios e secos, anticiclónicos, e as áreas onde se vão formar, dependem de um complexo número de factores. É por isso difícil estabelecer áreas preferenciais de ocorrência de pipkrakes, sem conhecermos o seu comportamento, quanto aos parâmetros apontados por OUTCALT (1971). As características microclimáticas são de extrema importância, e especialmente aquelas que respeitam à progressão da frente de congelação no solo. A complexidade resultante do comportamento térmico dos diferentes tipos de solo, aliada a outros factores, para os quais dificilmente se conseguem dados com regularidade, como por exemplo, a humidade $\mathrm{e}$ o gradiente de temperatura no solo, tornam a compreensão do mecanismo de formação de pipkrakes ainda mais difícil.

Na Serra do Gerês, foi possível observar diversas microformas cuja génese parece estar relacionada com a acção dos pipkrakes. A sobreposição dos processos hídricos, muito mais frequentes e com maior capacidade morfogenética, dá à micromorfologia observada um carácter efémero. Os pipkrakes funcionam, no entanto, como um processo importante, especialmente por prepararem o substrato para a erosão por outros processos, que vão transportar o material por eles desagregado. É ainda de realçar a importância do Homem, como factor ampliador da área de ocorrência de pipkrakes, em especial, ao destruir a cobertura vegetal, quer arbórea, quer arbustiva ou herbácea.

\section{AGRADECIMENTOS}

Ao Prof. António de Brum Ferreira, meu orientador, agradeço todo o apoio que me tem prestado na investigação que tenho vindo a desenvolver.

Gostaria de agradecer ainda, pela bibliografia gentilmente enviada, aos Professores Francisco L. Pérez (Univ. Texas, Austin, E.U.A.), Charles Harris (Univ. Gales, Cardiff, Reino Unido), Julia Branson (Univ. Southampton, Reino Unido) e Damian M. Lawler (Univ. Birmingham, Reino Unido).

O trabalho de campo efectuado na Serra do Gerês teria sido praticamente impossivel sem a ajuda logística prestada pelo Parque Nacional da Peneda-Gerês, especialmente pelos Engenheiros Paulo Cunha e Carlos Pinto. Agradeço também a ajuda do pessoal das delegações do Gerês e de Montalegre.

\section{BIBLIOGRAFIA}

ARnAEZ VADILlO, J. (1983) - Factores condicionantes de la formación de pipkrakes en una montaña oceanica (S. Demanda, Sistema Ibérico, España), VIII Coloquio de Geógrafos Españoles, Comunicaciones: 73-83.

ARNAEZ VADILLO, J. (1987) - Formas y processos en la evolución de vertientes de la Sierra de la Demanda (Sistema Ibérico), Cuadernos de Investigacion Geográfica, T. XIII (1-2): 9-153.

BEATY, C. B. (1974) - Needle ice and wind in the White Mountains of California, Geology, 2 (11): 565-567.

BIROT, P. (1981) - Les processus d'érosion à la surface des continents, Masson, Paris. 
BRANSON, J.; D. M. LAWLER; J. W. GLEN (1992) - The laboratory simulation of needle ice, in MAENO e HONDOH (eds.), Physics and chemistry of ice, Hokkaido Univ. Press, Sapporo: 357-363.

Coudé-Gaussen, G. (1981) - Les Serras da Peneda et do Gerês. Étude géomorphologique, Mem. C.E.G. $\mathrm{n}^{\circ} 5$, Lisboa.

DAveAu, S. (1978) - Le périglaciaire d'altitude au Portugal, Colloque sur le périglaciaire d'altitude du domaine mediterranéen et abords, Strasbourg 12-14 mai 1977: 63-78.

Daveau, S.; C. Coelho; V. G. Costa; L. Carvalho (1977) - Répartition et rythme des précipitations au Portugal, Mem. C.E.G., nº3, Lisboa.

Daveau, S. et al. (1985) - Mapas climáticos de Portugal: Nevoeiro e nebulosidade; Contrastes térmicos, Mem. C.E.G. no ${ }^{\circ}$, C.E.G., Lisboa.

FRENCH, H. M. (1976) - The Periglacial environment, Longman, London.

GEIGER, R. (1980) - Manual de microclimatologia. O clima da camada de ar junto ao solo, F.C.G., Lisboa.

GIRÃO, A. (1940) - Montemuro. A mais desconhecida serra de Portugal. Coimbra Ed., Coimbra.

HAGEDORN, J. (1974) - Note on the ocurrence of needle ice phenomena in the Southern Sinai Mountains, Zeitschrift für Geomorphologie, Suppl. Bd. 21: 35-38.

HALL, K. (1979) - Sorted stripes orientated by wind action: some observations from sub-Antarctic Marion Island, Earth Surface Processes, 4: 281-289.

HARRIS, C.; M. GALlOP; J-P. COUTARD (1993) - Physical modelling of gelifluction and frost creep: some results of a large-scale laboratory experiment, Earth Surface Processes and Landforms, 18: 383-398.

HASTENRATH, S. (1973) - Observations on the periglacial morphology of Mts. Kenya and Kilimanjaro, East Africa, Zeitschrift für Geomorphologie, Suppl. Bd. 16: 161-179.

HASTEnRATH, S. (1977) - Observations on soil frost phenomena in the Peruvian Andes, Zeitschrift für Geomorphologie, 21 (3): 357-362.

HÖLLERMANN, P. (1978) - Soil movements in the subtropical mountain environment of high Tenerife (Canary Islands), Colloque sur le périglaciaire d'altitude du domaine mediterranéen et abords, Strasbourg 12-14 mai 1977: 91-111.

JENNINGS, J. N. (1983) - Needle ice raked ground, Australian Geographer, 15(5): 328-330.

LAWLER, D. M. (1986) - River bank erosion and the influence of frost: a statistical examination, Transactions Institute of British Geographers, N.S., 11: 227-242.

LAWLER, D. M. (1987) - Bank erosion and frost action: an example from South Wales, in V. GARDINER (ed.), International geomorphology, Part I, John Wiley \& Sons, Chichester.

LAWLER, D. M. (1989) - Some observations on needle ice, Weather, 44: 406-409.

LAWLER, D. M. (1993) - Needle ice processes and sediment mobilization on river banks: the river Ilston, West Glamorgan, U.K., Journal of Hydrology, 150: 81-114.

Marques, M. A.; A. Sole; E. Mora; C. Llasat (1990) - Frost action features as a consequence of fire devegetations in a montane mediterranean environment, Catena, 17 (2): 163-174.

OutCALT, S. I. (1971) - An algorithm for needle ice growth, Water Resources Research, 7 (2): 394-400 .

Pedrosa, A. S. (1992) - A Serra do Marão: Evolução no Quaternário e dinâmica actual, Livro guia da visita de estudo, VI Colóquio Ibérico de Geografia, Porto.

Pedrosa, A. S. (1993) - A Serra do Marão. Estudo de geomorfologia, Dissertação de doutoramento apresentada à Faculdade de Letras da Universidade do Porto, Porto.

PÉREZ, F. L. (1986) - The effect of compaction on soil disturbance by needle ice growth, Acta Geocriogenica, 4: 11-119.

PeREZ, F. L. (1987a) - Le transport de cailloux par la glace d'exsudation dans les Hautes Andes (Vénézuela), Revue de Géomorphologie Dynamique, XXXVI (2): 33-51.

PÉREZ, F. L. (1987b) - Soil surface roughness and needle ice-induced particle movement in a Venezuelan Paramo, Carib. J. Sci., 23 (3-4): 454-460.

PÉREZ, F. L. (1987c) - Needle-ice activity and the distribution of Stem-rosette species in the Venezuelan páramo, Arctic and Alpine Research, 19 (1): 135-153.

PÉREZ, F. L. (1988) - The movement of debris on a high Andean talus, Zeitschrift für Geomorphologie, N. F., 32 (1): 77-99.

PÉREZ, F. L. (1992a) - Miniature sorted stripes in the páramo de Piedras Blancas (Venezuelan Andes), in J. C. DiXon e A. D. ABRAhAms (eds), Periglacial geomorphology, John Wiley \& Sons.

PÉREZ, F. L. (1992b) - Processes of turf exfoliation (Rasenabschälung) in the High Venezuelan Andes, Zeitschrift für Geomorphologie, N. F., 36 (1): 81-106. 
RAMOS, C. (1987) - A influência das situações anticiclónicas no regime da precipitação em Portugal, Finisterra, XXII (43): 5-38.

Rebelo, F. (1975) - Os processos erosivos actuais no Norte e Centro de Portugal (Projecto de investigação), Coimbra.

SoOns, J. M.; D. E. GREENLAND (1970) - Observations on the growth of needle ice, Water Resources Research, 6 (2): 579-593.

WASHBURN, A. L. (1979) - Geocryology. A survey of periglacial processes and environments, Edward Arnold, London.

WOODLEY, K. E. (1988) - Ice pictures, Weather, 43 (1): 10-17.

VIEIRA, G. T. (1995) - Processos morfogenéticos recentes e actuais na Serra do Gerês. Dissertação de Mestrado em Geografia Física e Ambiente apresentada à Faculdade de Letras da Universidade de Lisboa, Lisboa. 